\title{
The Role of Intragastric Balloon on EBL \%, Homeostasis of Lipid and Satiety Hormone
}

\author{
Asawer Hasan Najm¹, Hana'a Addai Ali ${ }^{2}$, Safauldeen Salim ${ }^{3}$ \\ 1, 2, 3 Kufa University, College of science, Chemistry department, AL-Najaf, Iraq
}

\begin{abstract}
The prevalence of obesity is increasing worldwide. Obesity is associated with a number of health related problems, so treating obesity is an important clinical concern. Intra-gastric balloon (IGB) represents, in the short-term, an alternative for obese patients non responding to diet and reluctant to surgery. Use of intragastric balloon for 6 months significantly reduces body weight and BMI. Moreover, Intragastric balloon strongly affects glucose homeostasis, lipid metabolism in addition to hormones involved in energy balance mainly serum leptin and ghrelin.
\end{abstract}

Keywords: Obesity, Intragastric balloon, Body mass index, weight loss, Ghrelin, Leptin, Follow-up.

\section{Introduction}

Obesity is a major cause of morbidity and mortality worldwide [1]. Numerous diseases are caused or worsened by obesity shortening life expectancy and decreasing quality of life as well [2],[3]. Treatment of obesity relies mainly on prolonged hypocaloric diet, associated with behavioural changes, drugs or surgery. Hypo-caloric diet is the mainstay of first-line treatment, but longterm response is difficult to achieve. Surgery, mainly represented by laparoscopic adjustable gastric banding (LAGB), sleeve gastrectomy, and Roux-en-Y gastric by-pass (RYGB), markedly reduces body weight and medical complications of obesity [4],[5]. However, serious complications may occur and many morbidly obese patients are reluctant to surgery. Bariatric surgery is an irreversible process [6].

Obese subjects who do not qualify for, or do not give consent to, bariatric surgical procedures constitute a therapeutic problem. An endoscopic method for the treatment of obesity, intragastric balloon, can be an option for this group of patients [7].

A number of hormones take part in the regulation of energy balance of the body, including two major ones, ghrelin, synthesized and secreted by $\mathrm{A} / \mathrm{X}$ cells of the proximal stomach mucosa, and leptin, synthesized mainly by adipose tissue and to a lesser degree in the stomach [8]. The peptides ghrelin and leptin have emerged in the last decade as the most influential contra-regulatory candidates in appetite and energy metabolism regulation [9]-[11].

Ghrelin, a 28-amino acid peptide secreted mainly by the stomach [12]. Ghrelin stimulates both energy gain and the secretion of growth hormone $(\mathrm{GH})$ and insulin leading to weight gain and attainment of a positive energetic balance in the long term [13]. In addition, Ghrelin levels seem to be influenced by age, gender, BMI, growth hormone, glucose, and insulin [14]. Leptin, a 167-amino acid protein produced by adipocytes in the hypothalamus is opposite to that of Ghrelin molecule [15]. Leptin is proportionally released to the amount of fat stored in the white adipose tissue and acts in hypothalamic suppression of food intake and increase in energy expenditure [16].

Three studies examined ghrelin concentrations during intragastric balloon treatment with divergent results [17] [19]. One study reported decreased fasting ghrelin concentrations after a balloon-induced weight loss of $9.4 \%$ [17]. A second study found similar meal-suppressed ghrelin concentrations in a sham-controlled design [18]. A third study noted increased ghrelin values after 1-month of intragastric balloon treatment that normalised to pretreatment levels 3 months after balloon removal [7].

The aim of our study was to prospectively assess the ghrelinand leptin-induced changes before intragastric balloon treatment and at 2, 4 \& 6 months of follow-up.

\section{Subjects and Methods}

The study was conducted on 26 obese patients who presented for intragastric balloon insertion in the Ibn Bilal private hospital during the period from June 2015 until the end of February 2016.

Intragastric balloon was inserted into the gastric fundus and then filled under endoscopic control with $600 \mathrm{ml}$ of saline stained with methylene blue. When the patients could take a fluid diet, they were discharged with drug therapy of lansoprazole and butylscopolamine. The patients remained on the fluid diet after the procedure and a 1,100-kcal/day diet was initiated after 1 week. At the end of the 6 -month period, the intragastric balloon was removed endoscopically.

Our patients were 11 men and 15 women, ranging from18-45 years of age (mean age 32.42 \pm 8.9 years). All patients participating in the study were subjected to complete medical history (including eating habits and previous treatment), measurement of body weight $(\mathrm{Kg})$, height $(\mathrm{m}), \mathrm{BMI}\left(\mathrm{Kg} / \mathrm{m}^{2}\right)$, fat percent (\%), Fasting blood glucose $(\mathrm{mg} / \mathrm{dl})$, Glycated Hemoglobin (HbA1c\%), complete lipid profile (cholesterol (mg/dl), triglycerides (mg/dl) , LDL (mg/dl), HDL , (mg/dl) VLDL (mg/dl), serum level of human Ghrelin (ng/ml) and Leptin (ng/ml) were recorded at baseline, 2, 4 and 6 months from the baseline. 


\section{International Journal of Science and Research (IJSR) \\ ISSN (Online): 2319-7064 \\ Index Copernicus Value (2013): 6.14 | Impact Factor (2014): 5.611}

Descriptive data were expressed as mean \pm SD. Baseline and outcome variables were compared with paired T test. An independent samples $\mathrm{T}$ test was used for different groups. To evaluate the association of leptin throughout 2, 4 and 6 months of follow up Pearson correlation" was employed. A $\mathrm{p}$ value of $<0.05$ was used to express significant statistical difference. The computer software used for analysis was SPSS 20.0 .

\section{Results}

Table 1 demonstrates four measurements for patients $(n=26)$, the first measurement was before Intragastric balloon (base line characteristics) ,while second measurement was two months after Intragastric balloon, the third measurement was four months after Intragastric balloon and the fourth reading was six months after Intragastric balloon with the mean \pm SD of all studied parameters. It can be noticed from table (3-1) that the mean values of each of body weight $(117.192 \pm 30.415 \mathrm{~kg})$, body mass index (43.019 \pm 11.135 $\mathrm{kg} / \mathrm{m} 2)$ and fat percent $(48.818 \pm 15.475 \%)$ were significantly declined after two months of gastric balloon $(\mathrm{p}=<0.001$ respectively) compared with that of preoperative means $(127.576 \pm 33.133 \mathrm{~kg}, \quad 47.176 \pm 12.027 \mathrm{~kg} / \mathrm{m} 2$ and $54.073 \pm 16.157 \%$ respectively), and the mean values of body weight (107.923 $\pm 28.906 \mathrm{~kg})$, BMI $(39.392 \pm 10.567 \mathrm{~kg} / \mathrm{m} 2)$ and fat percent $(44.725 \pm 14.835 \%)$ were significantly declined after four months of Intragastric balloon $(\mathrm{p}=$ $<0.001$ ) compared with means of pre-operative group, also there are declined in the mean \pm SD of these parameters after six months of this procedure $(96.923 \pm 26.173 \mathrm{~kg}$, $35.465 \pm 9.87 \mathrm{~kg} / \mathrm{m} 2$, fat percent $40.02 \pm 14.089 \%$ respectively) with a significant difference $(p=<0.001)$.

There are increasing in the mean of EBL\% during 2, 4 and 6 months post-operative $(22.252 \pm 13.121,41.622 \pm 23.78$ and $63.377 \pm 31.276 \%$ respectively) according to continuous dropping in the BMI and weight.

After two months of Intragastric balloon , mean fasting blood glucose $(89.346 \pm 9.995 \mathrm{mg} / \mathrm{dl})$ was significantly declined $(\mathrm{p}=$ $<0.001)$ compared with pre-operative mean value $(99.769 \pm 20.424 \mathrm{mg} / \mathrm{dl})$ also there is a significant decreased $(\mathrm{p}=<0.001)$ was noticed in mean level of HbA1c \% $(5.23 \pm 0.373)$ compared with pre-operative mean value (5.67 \pm 0.493$)$.

After four months of Intragastric balloon , the mean values of fasting blood glucose $(84.192 \pm 6.222)$ and HbA1c \% $(5.528 \pm 0.511)$ in patients were significantly decreased $(\mathrm{p}=$ $<0.001$ ) compared with pre-operative mean values. Six months post-operative showed declining mean in both of fasting blood glucose $(82.192 \pm 5.122 \mathrm{mg} / \mathrm{dl})$ and HbA1c \% (5.157 \pm 0.32$)$ with $\mathrm{p}$-value $=<0.001$.

After two months of Intagastric balloon, the mean values of serum total cholesterol $(166.807 \pm 42.035 \mathrm{mg} / \mathrm{dl})$, TG $(113.038 \pm 30.158 \mathrm{mg} / \mathrm{dl})$, LDL $(109.7 \pm 40.977 \mathrm{mg} / \mathrm{dl})$ and VLDL $(22.607 \pm 6.031 \mathrm{mg} / \mathrm{dl})$ were significantly decreased $(\mathrm{p}=<0.001,0.001,0.01$ and 0.001 respectively) compared with pre-operative mean values (176.038 \pm 48.02,
$118.73 \pm 33.45, \quad 119.346 \pm 49.221$ and $23.746 \pm 6.69 \mathrm{mg} / \mathrm{dl}$ respectively).

Each of total cholesterol, TG, LDL and VLDL were showed a significant decreasing $(\mathrm{p}=<0.001$ for total cholesterol and 0.001 for the others) in their mean value $(159.961 \pm 34.167$, 109.5 $\pm 27.228, \quad 100.83 \pm 32.735$ and $21.9 \pm 5.445 \mathrm{mg} / \mathrm{dl}$ respectively) after four months of Intagastric balloon compared with pre-operative means, also there are a significant decreasing $(\mathrm{p}=<0.001,0.003,<0.001$, and 0.003 respectively) in their means (154.807 \pm 29.338 , 104.384 $\pm 23.351,94.43 \pm 28.96$ and $20.876 \pm 4.67 \mathrm{mg} / \mathrm{dl}$ respectively) after six months compared with pre-operative means.

The mean value of serum HDL-cholesterol after two months $(34.5 \pm 7.156 \mathrm{mg} / \mathrm{dl})$ and after four months $(37.23 \pm 7.262$ $\mathrm{mg} / \mathrm{dl}$ ) of Intragastric balloon was significantly increased ( $\mathrm{p}=$ 0.04 and $<0.001$ respectively) compared with pre-operative mean value $(33 \pm 8.653 \mathrm{mg} / \mathrm{dl})$, also there is a significant increased $(\mathrm{p}=<0.001)$ in serum HDL-cholesterol mean $(39.5 \pm 6.772 \mathrm{mg} / \mathrm{dl})$ after six months of LSG compared with pre-operative mean value.

Mean serum ghrelin hormone two months post Intragastric balloon procedure $(0.488 \pm 0.153 \mathrm{ng} / \mathrm{ml})$ was significantly increased $(\mathrm{p}=<0.001)$ compared with pre-operative mean value $(0.451 \pm 0.165 \mathrm{ng} / \mathrm{ml})$, while its level $(0.429 \pm 0.15$ $\mathrm{ng} / \mathrm{ml})$ was significantly decreased $(\mathrm{p}=0.01)$ four months post Intragastric balloon compared with pre-operative mean, but there is a significant increasing $(\mathrm{p}=<0.001)$ in its level $(0.544 \pm 0.183 \mathrm{ng} / \mathrm{ml})$ after six months of Intragastric balloon, as presented in figure 1 .

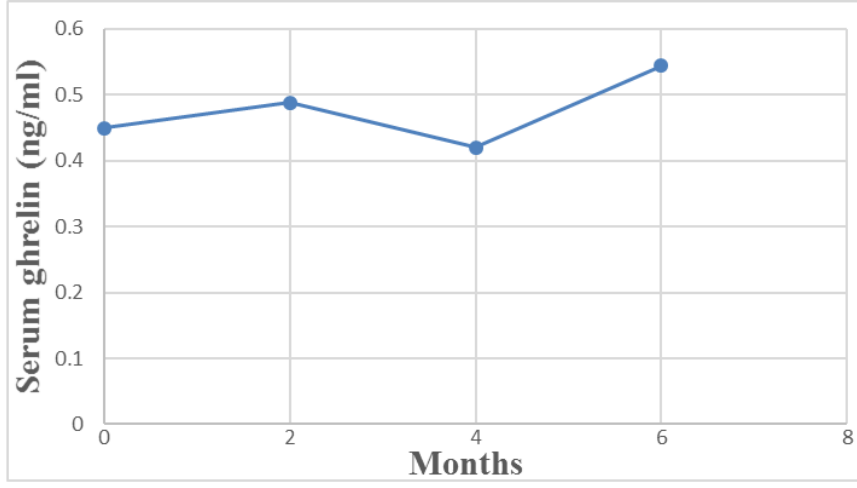

Figure 1: Ghrelin hormone levels in patients underwent Intragastric balloon pre- and 2, 4 \& 6 months post-operative

Finally the mean value of serum leptin after two months $(21.275 \pm 4.258 \mathrm{ng} / \mathrm{ml})$, four months $(17.568 \pm 4.021 \mathrm{ng} / \mathrm{ml})$ and six months $(18.355 \pm 4.034 \mathrm{ng} / \mathrm{ml})$ of Intragastric balloon was significantly decreased $(\mathrm{p}=<0.001)$ compared with the pre-operative mean value $(26.222 \pm 5.077 \mathrm{ng} / \mathrm{ml})$, as illustrative in figure 2. 


\section{International Journal of Science and Research (IJSR)}

ISSN (Online): 2319-7064

Index Copernicus Value (2013): 6.14 | Impact Factor (2014): 5.611

$$
\text { Patients }(n=26)
$$

\begin{tabular}{|c|c|c|c|c|}
\hline \multirow[t]{2}{*}{ Studied parameter } & Pre-operative base line & Two months post-operative & Four months post-operative & Six months post-operative \\
\hline & Mean $\pm S D$ & Mean $\pm S D$ & Mean $\pm S D$ & Mean $\pm S D$ \\
\hline Body weight (kg) & $127.576 \pm 33.133$ & $\begin{array}{c}117.192 \pm 30.415 \\
p=(<0.001)\end{array}$ & $\begin{array}{c}107.923 \pm 28.906 \\
p=(<0.001)\end{array}$ & $\begin{array}{c}96.923 \pm 26.173 \\
p=(<0.001)\end{array}$ \\
\hline$B M I\left(\mathrm{~kg} / \mathrm{m}^{2}\right)$ & $47.176 \pm 12.027$ & $\begin{array}{c}43.019 \pm 11.135 \\
p=(<0.001)\end{array}$ & $\begin{array}{c}39.392 \pm 10.567 \\
p=(<0.001)\end{array}$ & $\begin{array}{l}35.465 \pm 9.87 \\
p=(<0.001)\end{array}$ \\
\hline Fat percent \% & $54.073 \pm 16.157$ & $\begin{array}{c}48.818 \pm 15.475 \\
p=(<0.001)\end{array}$ & $\begin{array}{c}44.725 \pm 14.835 \\
p=(<0.001)\end{array}$ & $\begin{array}{c}40.02 \pm 14.089 \\
p=(<0.001)\end{array}$ \\
\hline$E B L \%$ & & $22.252 \pm 13.121$ & $41.622 \pm 23.78$ & $63.377 \pm 31.276$ \\
\hline$F B G(m g / d l)$ & $99.769 \pm 20.424$ & $\begin{array}{c}89.346 \pm 9.995 \\
p=(<0.001)\end{array}$ & $\begin{array}{c}84.192 \pm 6.222 \\
p=(<0.001)\end{array}$ & $\begin{array}{c}82.192 \pm 5.122 \\
p=(<0.001)\end{array}$ \\
\hline HbA1c \% & $5.67 \pm 0.493$ & $\begin{array}{l}5.528 \pm 0.511 \\
p=(<0.001)\end{array}$ & $\begin{array}{l}5.23 \pm 0.373 \\
\mathrm{p}=(<0.001)\end{array}$ & $\begin{array}{l}5.157 \pm 0.32 \\
p=(<0.001)\end{array}$ \\
\hline Cholesterol (mg/dl) & $176.038 \pm 48.02$ & $\begin{array}{c}166.807 \pm 42.035 \\
\mathrm{p}=(<0.001)\end{array}$ & $\begin{array}{c}159.961 \pm 34.167 \\
\mathrm{p}=(<0.001)\end{array}$ & $\begin{array}{c}154.807 \pm 29.338 \\
\mathrm{p}=(<0.001)\end{array}$ \\
\hline$T G(m g / d l)$ & $118.73 \pm 33.45$ & $\begin{array}{c}113.038 \pm 30.158 \\
p=(0.001)\end{array}$ & $\begin{array}{c}109.5 \pm 27.228 \\
p=(0.001)\end{array}$ & $\begin{array}{c}104.384 \pm 23.351 \\
p=(0.003)\end{array}$ \\
\hline HDL (mg/dl) & $33 \pm 8.653$ & $\begin{array}{c}34.5 \pm 7.156 \\
p=(0.04)\end{array}$ & $\begin{array}{l}37.23 \pm 7.262 \\
p=(<0.001)\end{array}$ & $\begin{array}{l}39.5 \pm 6.772 \\
p=(<0.001)\end{array}$ \\
\hline$L D L(m g / d l)$ & $119.346 \pm 49.221$ & $\begin{array}{c}109.7 \pm 40.977 \\
\mathrm{p}=(0.01)\end{array}$ & $\begin{array}{c}100.83 \pm 32.735 \\
p=(0.001)\end{array}$ & $\begin{array}{l}94.43 \pm 28.96 \\
p=(<0.001)\end{array}$ \\
\hline$V L D L(m g / d l)$ & $23.746 \pm 6.69$ & $\begin{array}{c}22.607 \pm 6.031 \\
p=(0.001)\end{array}$ & $\begin{array}{l}21.9 \pm 5.445 \\
p=(0.001)\end{array}$ & $\begin{array}{c}20.876 \pm 4.67 \\
p=(0.003)\end{array}$ \\
\hline Ghrelin (ng/ml) & $0.451 \pm 0.165$ & $\begin{array}{l}0.488 \pm 0.153 \\
p=(<0.001)\end{array}$ & $\begin{array}{c}0.429 \pm 0.15 \\
p=(0.01)\end{array}$ & $\begin{array}{l}0.544 \pm 0.183 \\
p=(<0.001)\end{array}$ \\
\hline Leptin (ng/ml) & $26.222 \pm 5.077$ & $\begin{array}{c}21.275 \pm 4.258 \\
p=(<0.001)\end{array}$ & $\begin{array}{c}17.568 \pm 4.021 \\
p=(<0.001)\end{array}$ & $\begin{array}{c}18.355 \pm 4.034 \\
p=(<0.001)\end{array}$ \\
\hline
\end{tabular}

p: probability level, significant at $p<0.05$. BMI Body mass index, EBL\% Excess body mass index loss percent, FBG Fasting blood glucose, TG Triglyceride, HDL High density lipoprotein, LDL Low density lipoprotein, VLDL Very low density lipoprotein.

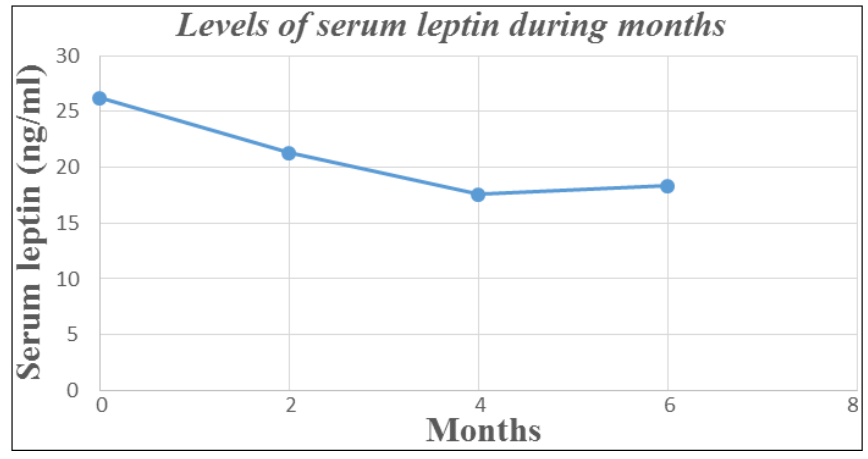

Figure 2: Leptin hormone levels in patients underwent Intragastric balloon pre- and 2, 4 \& 6 months post-operative.

Leptin was positively correlated with LDL at 2 months of follow up and with Fat percent at 6 months, while negatively correlation was shown with HDL after 4 months of follow up (Table 2).

Table 2: Pearson correlation between leptin and LDL, HDL \& Fat \% during follow up

\begin{tabular}{|c|c|c|c|c|}
\hline & 2 Months & 4 Months & 6 Months \\
\hline & & LDL & HDL & Fat $\%$ \\
\hline \multirow{2}{*}{ LEPTIN } & $\mathrm{r}$ & 0.409 & -0.39 & 0.421 \\
\hline & $p$ & 0.038 & 0.04 & 0.03 \\
\hline
\end{tabular}

$r$ Pearson correlation coefficient, correlation is significant at the 0.05 level (2-tailed), LDL Low density lipoprotein, HDL High density lipoprotein.
The 6-month treatment with Intragastric balloon caused a significant reduction in serum leptin concentration. A decrease in the amount of adipose tissue after balloon application resulted in a diminution of serum leptin level. In clinical studies, a decrease in leptin level was observed after body mass reduction due to diet or bariatric surgery [38], [39].

\section{Discussion}

The intragastric balloon has been shown to be a safe and effective procedure for temporary weight reduction, with low mortality and morbidity [19].Intragastric balloons have played an essential role in the preoperative treatment of morbidly obese patients who are scheduled to undergo bariatric or other elective surgery by minimizing mortality and morbidity risks [20].

The placement of the intragastric balloon for 6 months resulted in a statistically significant reduction in body weight. The declining in our weight results are comparable to previous reports in which the weight loss was $14.7-17.8 \mathrm{~kg}$ and BMI loss was $5.7-6.7 \mathrm{~kg} / \mathrm{m} 2$ [21]-[23]. Similar results were obtained by others [24]-[26].

The fat percent \% decreased on average by 14 during the 6 month period. The loss of body fat is the most important objective of obesity treatment. However, the current decline of fat is often observed. Maintenance of fat-free mass is of particular importance in obesity treatment to minimize the reduction in energy expenditure seen after weight loss. This may be a result of the negative energy balance, lower body weight, and less stimulation for muscle growth in the lower limbs [27]-[29]. 


\section{International Journal of Science and Research (IJSR) \\ ISSN (Online): 2319-7064 \\ Index Copernicus Value (2013): 6.14 | Impact Factor (2014): 5.611}

In this study we found a positive effect of the Intragastric balloon insertion on serum glucose. The observed improvement of glycated hemoglobin levels was statistically significant. Moreover, there is significant reduction in fasting glucose levels. Decreases in glycated hemoglobin in patients with Intragastric balloon were reported in several studies. Sekino describes a decrease in glycated hemoglobin; however, this decrease was not statistically significant [30]. In a 6-month study with Intragastric balloon, KonopkoZubrycka documented a significant decrease in fasting glucose and insulin response [7]. Similar results were seen by Mathus-Vliegen in their randomized study [31]-[33].

In this study we noticed that insertion of Balloon for 6 months caused a significant reduction in serum cholesterol, triglycerides and LDL and there is a significant increase in serum HDL was found. These results are in agreement with those of Konopko-Zubrzycka et al. who stated that in patients with morbid obesity treated with BIB, weight loss was accompanied by a decrease in total cholesterol by $17.6 \%$ ( $<$ $0.001)$, triglycerides by $25.5 \%(\mathrm{p}<0.01)$ and LDL by $27.5 \%$ $(\mathrm{p}<0.001)$ and increase in plasma HDL [7].

Biological effects of ghrelin appear to be the opposite of those of leptin, which has been suggested to be the key signal reflecting adipose stores [34].

In our study, plasma leptin significantly decreased, probably reflecting the drop in body fat, whereas plasma ghrelin increased. In a previous study of non-morbidly obese patients treated with intragastric balloon, plasma levels of leptin and ghrelin significantly decreased 6 months after balloon insertion [35]. In another study of obese Caucasians receiving balloon, plasma leptin decreased during the first 3 months after balloon placement, then remained stable during 3 months [36]. Yet another study compared subjects with an Intragastric balloon placed for 6 months to 15 morbidly obese controls treated with a low-calorie diet. Plasma leptin decreased and plasma ghrelin increased by a third one month after balloon placement, then decreased reaching the starting level 3 months after removal [7]. Overall, during the 6 months with balloon, plasma leptin always decrease, whereas plasma ghrelin peaks during the first 3 months after placement then decreases.

Mion et al. reported the effect of air-filled balloon on weight reduction and ghrelin concentration in nonmorbidly obese patients. The insertion of the balloon resulted in a marked reduction of body weight and increase in plasma ghrelin concentration. The plasma ghrelin rose significantly 1 month after the balloon placement and returned to the initial level 4 months after the placement of the air balloon [35].

In the present study, we observed a similar increase in plasma ghrelin 2 months after the balloon insertion; however the marked decrease of the ghrelin level was observed 4 months after the balloon removal. However, it should be noted that, in experimental studies, the extension of the stomach wall by direct delivery of water to the stomach did not affect ghrelin concentration [36]. three studies with the introduction of the intragastric balloon in morbidly obese patients [14]. The concentration continued to fall at lesser marginal levels until the end of the study. Furthermore, the decrease in leptin concentrations showed a correlation to the fat percent \%. This effect might be ameliorative on obesity-related comorbidities [37].

\section{References}

[1] R. Ganesh, A. Rao, H. Baladas, T. Leese. The Bioenteric Intragastric Balloon (BIB) as a treatment for obesity: poor results in Asian patients," Singapore Med J., (48), pp. 227-31, 2007.

[2] Obesity: Preventing and managing the global epidemic. Report of WHO consultation. 2000; Technical Repor Series $n^{\circ}$ 894. WHO: Obesity and overweight. Global Strategy on Diet, Physical Activity and Health. Available at: $\quad$ www.who.int/nutrition/publications/obesity/ WHO_TRS_894/, Geneva: 2003.

[3] D. Heber. An integrated view of obesity," Am J Clin Nut, (91), pp. 280S-3S, 2010.

[4] P. O'Brien. Bariatric surgery: mechanisms, indications and outcomes," J Gastroenterol Hepatol, (25), pp. 13581365, 2010.

[5] S. Eldar, H. Heneghan, S. Brethauer, P. Schauer. Bariatric surgery for treatment of obesity," Int J Obes., (35), pp. S16-S21, 2011.

[6] A. Genco, T. Bruni, S. Doldi et al. BioEnterics intragastric balloon": the Italian experience with 2,515 patients. Obes Surg, (15), pp. 1161-4, 2005.

[7] M. Konopko-Zubrzycka, A. Baniukiewicz, E. Wróblewski et al. The effect of intragastric balloon on plasma ghrelin, leptin, and adiponectin levels in patients with morbid obesity," J Clin Endocrinol Metab, 94 (5), pp. 1644-9. doi:10.1210/jc.2008-1083. PMID: 19258408. 2009.

[8] M. Kojima, H. Hosoda, Y. Date, M. Nakazato, H. Matsuo, K. Kangawa. Ghrelin is a growth-hormonereleasing acylated peptide from stomach," Nature, (402), pp. 656-660, 1999.

[9] M. Tschop, C. Weyer, P. Tataranni et al. Eirculating ghrelin levels are decreased in human obesity," Diabetes, (50), pp. 707-9, 2001.

[10]P. Havel. Peripheral signals conveying metabolic information to the brain: short-term and long-term regulation of food intake and energy homeostasis," Exp Biol Med, (226), pp. 963-77, 2001.

[11] J. Davis, D. Choi, J. Schurdak et al. Eeptin regulates energy balance and motivation through action at distinct neural circuits," Biol Psychiatry, (69), pp. 668-74, 2010.

[12] M. Kojima, H. Hosoda, Y. Date, et al. Ghrelin is a growth-hormone-releasing acylated peptide from stomach." Nature, 402(6762), pp. 656-660, 1999.

[13] D. Cummings, J. Purnell, R. Frayo, et al. A preprandial rise in plasma ghrelin levels suggests a role in meal initiation in humans" Diabetes, 50(8), pp. 1714 1719, 2001.

[14] M. Nikolic, M. Boban, N. Ljubicic, et al. Morbidly obese are ghrelin and leptin hyporesponders with lesser intragastric balloon treatment efficiency : ghrelin and

The decline in plasma leptin levels was similarly reported in

\section{Volume 5 Issue 3, March 2016}




\section{International Journal of Science and Research (IJSR) \\ ISSN (Online): 2319-7064}

Index Copernicus Value (2013): 6.14 | Impact Factor (2014): 5.611

leptin changes in relation to obesity treatment," Obes Surg, 21(10), pp. 1597-1604, 2011.

[15] E. Roubos, M. Dahmen, T. Kozicz, et al. Heptin and the hypothalamo-pituitary-adrenal stress axis," Gen Comp Endocrino, 177(1), pp. 28-36, 2012.

[16] B. Belgardt, J. Brüning. - ENS leptin and insulin action in the control of energy homeostasis," Ann N Y Acad Sci., (1212), pp. 97-113, 2010.

[17]F. Mion, B. Napoleon, S. Roman, et al. Effects of intragastric balloon on gastric emptying and plasma ghrelin levels in non-morbid obese patients," Obes Surg, (15), pp. 510-6, 2005.

[18] M. Martinez-Brocca, O. Belda, J. Parejo, et al. fntragastric ballooninduced satiety is not mediated by modification in fasting or postprandial plasma ghrelin levels in morbid obesity," Obes Surg, (17), pp. 649-57, 2007.

[19] A. Genco, M. Cipriano, V. Bacci, et al. BioEnterics intragastric balloon (BIB): a short-term, double-blind, randomised, controlled, crossover study on weight reduction in morbidly obese patients," Int J Obes, 30(1), pp. 129-33, 2006.

[20] A. Genco, S. Balducci, V. Bacci, et al. Intragastric balloon or diet alone? A retrospective evaluation," Obes Surg, 18(8), pp. 989-92, 2008. doi:10.1007/s11695-0079383-9. May 16. PMID: 18483834

[21] I. Imaz, C. Martínez-Cervell, E. García-Alvarez, et al. Safety and effectiveness of the intragastric balloon for obesity. A meta-analysis," Obes Surg, 18(7), pp. 841-6, 2008. doi:10.1007/s11695-007-9331-8. May 6. Review. PMID: 18459025.

[22] J. Dumonceau.. Evidence-based review of the bioenterics intragastric balloon for weight loss," Obes Surg, 18(12), pp. 1611-7, 2008. doi:10. 1007/s11695008-9593-9. Jun 21. Review. PMID: 18568377.

[23] N. Crea, G. Pata, D. Della Casa, et al. Improvement of metabolic syndrome following intragastric balloon: 1 year follow-up analysis," Obes Surg, 19(8), pp. 1084-8, 2009. doi:10.1007/s11695-009-9879-6. Jun 9. PMID: 19506981.

[24]E. Lecumberri, W. Krekshi, P. Matía, et al. Effectiveness and safety of air-filled balloon Heliosphere BAG ${ }^{\circledR}$ in 82 consecutive obese patients," Obes Surg, 21(10), pp. 1508-12, 2011. doi:10.1007/s11695-010- 0314-9. PMID: 21221835.

[25] U. Dogan, Y. Gumurdulu, M. Akin, et al. Five percent weight lost in the first month of intragastric balloon treatment may be a predictor for long-term weight maintenance," Obes Surg, 23(7), pp. 892-6, 2013. doi: 10.1007/s11695-013-0876-4. PMID: 23404240.

[26] M. Konopko-Zubrzycka, A. Baniukiewicz, E. Wróblewski, et al. The effect of intragastric balloon on plasma ghrelin, leptin, and adiponectin levels in patients with morbid obesity," J Clin Endocrinol Metab, 94(5), pp. 1644-9, 2009. doi:10.1210/jc.2008-1083. PMID: 19258408.

[27]KK. Danielsen, M. Svendsen, S. Mæhlum, et al. - Changes in body composition, cardiovascular disease risk factors, and eating behavior after an intensive lifestyle intervention with high volume of physical activity in severely obese subjects: a prospective clinical controlled trial," J Obes, 2013. doi:
10.1155/2013/325464. Epub. Apr 22. PMID: 23710347; PMCID: PMC3654355.

[28] M. Weck, S. Bornstein, A. Barthel, et al. Strategies for successful weight reduction-focus on energy balance," DtschMedWochenschr, 137(43), pp. 2223-8, 2012. doi:10.1055/s-0032-1327232. Oct 17. Review. German. PMID: 23076670.

[29] T. Wycherley, G. Brinkworth, P. Clifton, et al. Eomparison of the effects of 52 weeks weight loss with either a high-protein or highcarbohydrate diet on body composition and cardiometabolic risk factors in overweight and obese males," Nutr Diabetes, 2012, 2:e40. doi:10.1038/nutd.11. PMID: 23448804; PMCID: PMC3432181.

[30] Y. Sekino, K. Imajo, E. Sakai, et al. Timecourse of changes of visceral fat area, liver volume and liver fat area during intragastric balloon therapy in Japanese super-obese patients," Intern Med, 50 (21), pp. 24492455, 2011.

[31]M. Konopko-Zubrzycka, A. Baniukiewicz, E. Wróblewski, et al. The effect of intragastric balloon on plasma ghrelin, leptin, and adiponectin levels in patients with morbid obesity," J Clin Endocrinol Metab, 94(5), pp. 1644-1649, 2009.

[32] T. Horvath, S. Diano, P. Sotonyi, M. Heimau, M. Tschop. Minireview: ghrelin and the regulation of energy balance hypothalamic perspective," Endocrinology, (142), pp. 4163-4169, 2001.

[33] F. Mion, B. Napoléon, S. Roman, E. Malvoisin, F. Trepo, B. Pujol, C. Lefort, R. Bory. Effects of intragastric balloon on gastric emptying and plasma ghrelin levels in non-morbid obese patients," Obes Surg, (15), pp. 510-516, 2005.

[34] M. Nikolic, M. Boban, N. Ljubicic, et al. Morbidly obese are ghrelin and leptin hyporesponders with lesser intragastric balloon treatment efficiency : ghrelin and leptin changes in relation to obesity treatment," Obes Surg, 21(10), pp. 1597-1604, 2011.

[35] F. Mion, R. Gincul, S. Roman, S. Beorchia, F. Hedelius, N. Claudel, R. Bory, E. Malvoisin, F. Trepo , B. Napoleon. Tolerance and efficacy of an air-filled balloon in non-morbidly obese patients: results of a prospective multicenter study," Obes Surg, (17), pp. 764-769, 2007.

[36] J. Herve, C. Wahlen, A. Schaeken, B. Dallemagne, J. Dewandre, S. Markiewicz, B. Monami, J. Weerts, C. Jehaes. What becomes of patients one year after the intragastric balloon has been removed?" Obes Surg, (15), pp. 864-870, 2005.

[37] B. Ahren, R. Baldwin, P. Havel. Pharmacokinetics of human leptin in mice and rhesus monkeys," Int J Obes Relat Metab Disord, (24), pp. 1579-85, 2000.

[38] T. Okasaki, E. Himeno, H. Nanri, H. Ogata, M. Ikeda. Effects of mild aerobic exercise and a mild hypocaloric diet on plasma leptin in sedentary women," Clin Exp Pharmacol, (26), pp. 415-420, 1999.

[39] M. Faraj, P. Havel, S. Phelis, D. Blank, A. Sniderman , K. Cianflone. Plasma acylation-stimulating protein, adiponectin, leptin, and ghrelin before and after weight loss induced by gastric bypass surgery in morbidly obese subjects," J Clin Endocrinol Metab (88), pp. 1594-1602, 2003.

\section{Volume 5 Issue 3, March 2016}




\section{Author Profile}

Asawer Hasan received the B.S degree in chemistry from Baghdad University, college of science in 2013; main fields of interest: biochemistry.

Hana'a Addai is an Asst. Prof. at University of Kufa, Faculty of Science, Department of Chemistry, Iraq; she has received his PhD from University of Babylon, Iraq in 2012; main fields of interest: biochemistry, scientific research pertaining to the chemical aspect of biomolecular and their reaction in vitro and in vivo.

Safauldeen Salim is a professor in general surgery, university of Kufa medical school; he has received MBChB in 1989 and FICMS in 1997. He has a member of WALS, member of Arab Lap Surgeon, member of Iraqi committee of medical specialization, member of Arab board in general surgery, general and lap surgeon in Alsader medical city; field of interest: lap surgery. 